\title{
Orbitolina episodes in carbonate platform evolution: the early Aptian model from SE Spain
}

\author{
Lorenzo Vilas $^{\text {a }}$, Jean Pierre Masse ${ }^{\mathrm{b}}$, Consuelo Arias ${ }^{\mathrm{a}}$ \\ ${ }^{a}$ Instituto de Geología Económica (CSIC-UCM), Dpto. Estratigrafía, Fac. C. Geológicas. Univ. Complutense, \\ 28040 Madrid, Spain \\ ${ }^{b}$ Centre de Sédimentologie/Paléontologie, URA 1208 du CNRS, Univ. de Provence, 3, Pl. V. Hugo, \\ 13331 Marseille Cedex 3, France
}

\begin{abstract}
Among the Orbitolininae, Palorbitolina lenticularis (Blumenbach) is a common facies marker in Upper BarremianLower Aptian shallow water Mesogean deposits and was hitherto ascribed to specific, but contrasting paleoenvironments within the carbonate platform facies suites. The Albacete-Prebetic area (SE Spain) illustrates a model in which the Palorbitolina facies spread over the whole platform system. The development of the Palorbitolina sediments coincided with a transgressive trend at the end of an important terrigenous period. This model could also be applied to similar Middle Cretaceous "Orbitolina" facies.
\end{abstract}

\section{Introduction}

"Orbitolina facies" are common in the carbonate platform sediment spectrum of the Mid Cretaceous. Deposits dominated by representatives of this group of large foraminifera are documented from the whole Mesogean realm (Douvillé, 1900; Masse, 1992). Orbitolina-bearing beds are frequently described as more or less "marly intercalations" (i.e. in nearly pure carbonates) with a relatively wide lateral extent.

The objectives of the present paper are twofold: - to document the occurrences of such "Orbitolina facies" in terms of palaeontology (i.e. taxonomy), autoecology and environmental settings,

- to illustrate from the regional example of the Lower Aptian sequences of the Albacete domain and the Murcia Prebetic margin (SE Spain) (Arias et al., 1987, 1991; Vilas et al., 1993), the sedimentologic meaning and importance of the beds in question within the carbonate platform ecosystem evolutionary patterns.

\section{Palaeontological aspects}

Orbitolinids pertain to two distincts subfamilies: Orbitolininae and Dictyoconinae (Moullade, 1965; Loeblich and Tappan, 1988) the splitting of which is mainly based upon the macrospheric embryo organization (Schroeder, 1963). However, distinctive morphologic trends are also taxonomically relevant. Large flat conical tests with a discoidal tendency are prominent features of the Orbitolininae whereas Dictyoconinae are essentially smaller and mainly conical, although some 
genera and/or species may exhibit large low conical tests.

"Orbitolina facies" mainly refers to the Orbitolininae, the time range of which is from the Barremian to the Cenomanian (Loeblich and Tappan, 1988). In the late Barremian-early Aptian the cardinal form of this group was Palorbitolina lenticularis (Blumenbach), a species known from Mexico (Meza, 1980), the Central Atlantic (Gupta and Grant, 1971), the Mediterranean, Middle East and African regions (Pelissie et al., 1982; Peybernès, 1982; Peybernès and Forster, 1987; Simmons and Hart, 1987), Borneo (Hofker, 1963) and the Philippines (Wolcke and Scholz, 1988).

The specific status of Palorbitolina lenticularis and the possibility of dividing this form in several distinctive species or subspecies have been debated (see discussion in Arnaud-Vanneau, 1980). Three aspects need to be pointed out:

- a high variability in test microstructure: from pure carbonate, with micritic or lutitic structure, to mixed quartz and bioclastis debris, especially sphaerical sponge spicules ("calcite eyes" sensu Douglass, 1960),

- a wide range of test size and morphology including variations in flatness, concavity or convexity of the oral face, apical angle, etc...,

- an increasing complexity and size through time of the macrospheric embryo (Gušić, 1981).

Whether these features could be relevant for specific taxonomy are not discussed here and we accept Palorbitolina lenticularis in the broad sense (e.g. Form group I sensu Hofker, 1963).

\section{Palaeoecology}

As a large foraminifer found in carbonate platform settings containing calcareous green algae and hermatypic corals, Palorbitolina lenticularis is indicative of warm waters and a shallow environment, a point of view substantiated by its palaeobiogeographic distribution. The question of a possible symbiosis with zooxantellae proposed by Hottinger (1982), also implies a relatively limited palaeobathymetric range. The size, morphology and test architecture suggest a free, epifaunal mode of life (Masse, 1976) instead of an epiphytic one which is assumed by Arnaud-Vanneau (1975). Considering modern analogues (Murray, 1991), the large size also implies a significant longevity (one or two years) and a relatively limited fecundity. Fecundity is assumed to be controlled by an asexual multiple fission mode of reproduction (Hallock, 1985), a phenomenon corroborated by the dominance of macrospheric forms over microspheric ones in well preserved populations of Palorbitolina lenticularis (Arnaud-Vanneau, 1968).

Whether the living animal was lying on the substrate by its apertural face (flat base of the cone), or by the apex, have been debated (Hofker, 1963; Arnaud-Vanneau, 1968, 1975). We favour here a close relationship between the apertural face and the sedimentary substrate.

Palorbitolina lenticularis is known from various types of sediments, but is specially abundant in muddy settings (pure carbonates, more or less marly), where it tends to be dominant. This dominance trend is expressed by the exclusion of nearly all macrobiotic elements, except isolated rudists, corals or brachiopods as well as some infaunal organisms, e.g. bivalves and echinoids. Associated microfauna is generally composed of small foraminifera or a few larger ones e.g. Choffatella decipiens Schlumberger.

\section{Previous models}

Despite its prominent character as a facies index, Palorbitolina lenticularis has been ascribed to a relatively wide range of palaeoenvironments. For Rey (1975) this species was living in the infralittoral zone (sensu Peres, 1961) both in agitated reefal settings and backreef muds, with a decreasing frequency towards the coastal zone with a high siliciclastic flux. For Arnaud-Vanneau (1975) it is considered an infralittoral epiphytic form, tightly linked to vegetation-covered substrates. For one of us (Masse, 1976) Palorbitolina lenticularis reflects deeper circalittoral conditions. In 1980 Arnaud-Vanneau mentioned the occurrence of this taxon in both infralittoral and circalittoral environments with or without vegetation. Arnaud (1981) stated the existence of three main settings: 
- finely bioclastic limestones with a circalittoral significance,

- caprinid calcareous muds with an infralittoral open marine meaning,

- "marly channels" in which Palorbitolina is the dominant organism.

Three distinctive subspecies of Palorbitolina lenticularis are ascribed to these three settings (Arnaud-Vanneau, 1980; Arnaud, 1981).

Similar biotopes are also inferred from sedimentological and palaeoecological investigations for the genus Mesorbitolina in the Albian of southern USA where this taxon was mainly described from open reefal or off-reef environments (Perkins, 1974; Scott, 1990).

The occurrence of Palorbitolina beds displaying a wide lateral extent, are known from the SE of France (Masse, 1976; Arnaud-Vanneau, 1981), Portugal (Rey, 1973; Cugny, 1975), southern Italy (Luperto-Sinni, 1979; Luperto-Sinni and Masse, 1982, 1992) and Tunisia (Masse, 1984). In these examples Palorbitolina beds are considered as guide levels for lithostratigraphic correlations and mapping purposes.

\section{The Spanish Iberic-Prebetic model}

\subsection{Previous data}

Palorbitolina bearing-beds fairly wide extent were mentioned by Fourcade (1970) from the Upper Barremian-Lower Aptian of the studied area; similar beds were also described by GarcíaHernández (1978) from the Prebetic domain, near Jaen, then by Company et al. (1982) in the Alicante region and by Champetier and Moullade (1970) in the Valencia area. In the southeastern part of the Iberic domain as well as in the Albacete domain, the Orbitolina beds have been documented by García (1977), Arias (1978), and Mas (1981). Palorbitolina beds were first used as guide levels and formal rock units with regional meaning by Arias et al. (1987).

\subsection{Geographic and geologic setting}

The studied area is located at the borders of the Albacete, Murcia and Valencia Provinces (Fig. 1).
Structurally it belongs to the Betic Cordillera to the south and to the Iberic domain to the north flanking the stable Meseta region.

The regional early Aptian palaeogeographic configuration shows:

- a southern domain: the Betic margin, corresponding to the southern edge of the Iberic plate, - a northern domain: the Iberic basin, an intraplate subsiding depression.

These two domains are separated by the stable Albacete region.

The stratigraphic organization is here summarized by three regional cross sections based on 13 measured sections (Fig. 2).

Cross section I deals with the Iberic basin and the Albacete eastern border; cross section II runs from the Albacete border to the Betic margin and cross section III concerns the Betic domain.

\section{Stratigraphy}

Aptian shallow water carbonates of SE Spain are divided into three depositional sequences with typical lithostratigraphic and biostratigraphic attributes clearly expressed at a regional scale (Vilas et al., 1993).

The lower sequence of Bedoulian p.p. age, shows three subsequences: the Palorbitolina-bearing beds investigated here pertain to the middle one (Arias et al., 1987). These beds are ascribed to the "Praeorbitolina biozone" (García-Hernández, 1981; Arias et al., 1987; Masse et al., 1992).

The figured cross sections I-III depict the whole subsequence to which pertain the Palorbitolinabearing beds (Fig. 2).

This subsequence records three successive episodes:

- a terrigenous episode dominated by continental and littoral clastics, the end of which marks the onset of a transgressive trend (lower episode in the correlation, Fig. 2).

- a carbonate episode: the Palorbitolina spreading phase coeval with a transgressive peak, the end of which sees the onset of a progradational trend (middle episode in the correlation, Fig. 2).

- a carbonate episode dominated by rudists (mainly requieniids) corresponding with the final major progradational phase, which is not always 


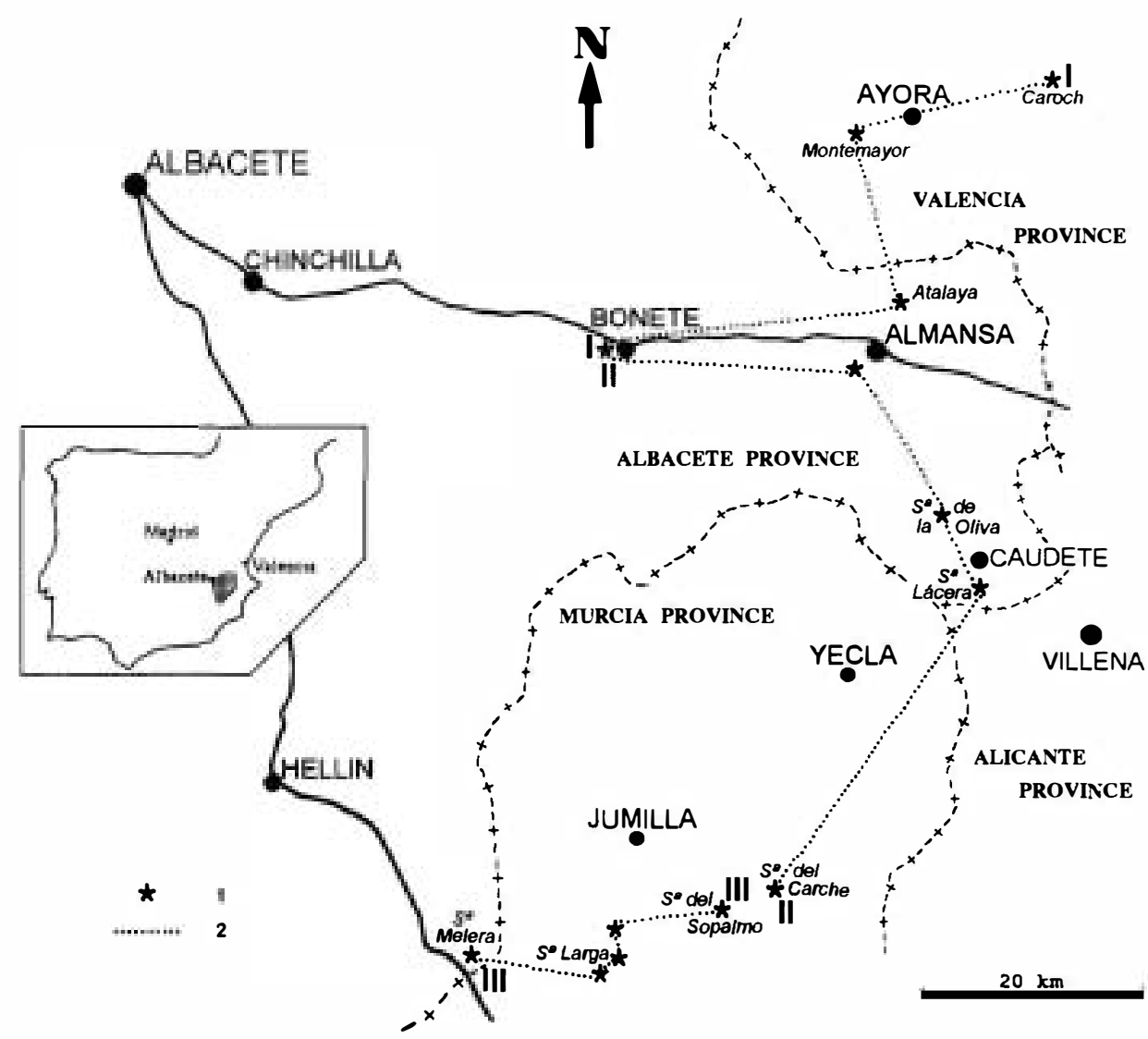

Fig. 1. Geographical setting. $l=$ Studied outcrops. $2=$ Location of the cross sections.

present in the studied sections, (upper episode in the correlation, Fig. 2).

\section{Depositional environments}

Investigations into the spatial distribution of facies corresponding to the Palorbitolina spreading phase show the existence of five major distinctive depositional environments involving specific facies types.

(1) Littoral zone deposits. Fine-grained siliciclastic sands and silts with flaser bedding and bioturbation are ascribed to this type of depositional environment. Locally, large scale cross bedded, channelized sands are also recorded. Some of the facies could be continental.

(2) Coastal zone deposits. Sandy dolomites and limestones are found in this zone. The siliciclastic content is highly variable but mainly represented by fine-grained material. The Palorbitolina record is meagre, and individuals are dispersed, frequently broken or poorly preserved (as the result of dolomitization). Palorbitolina is regarded as more or less allochthonous (derived from shoreward transport) or reworked in situ (Fig. 3). Locally thickshelled ostreids are present.

(3) Platform interior deposits. Palorbitolina-

Fig. 2. Correlation panel of the cross sections I, II and III shown in Fig. $1.1=$ Sands and gravels. $2=$ Fine sands and silts. $3=$ Sandy marls. $4=$ Outer shelf marls. $5=$ Limestones. $6=$ Dolomites, sandy dolomites. $7=$ Grainstones. $8=$ Kimmeridgian limestones. $a=$ Ostreids. $b=$ Orbitolines. $c=$ Solitary corals. $d=$ Equinoids. $e=$ Caprinids. $f=$ Colonial corals. $g=$ Requieniids. $h=$ Charophytes. $i=$ Bryozoan. Relative distance between the sections not to scale. 

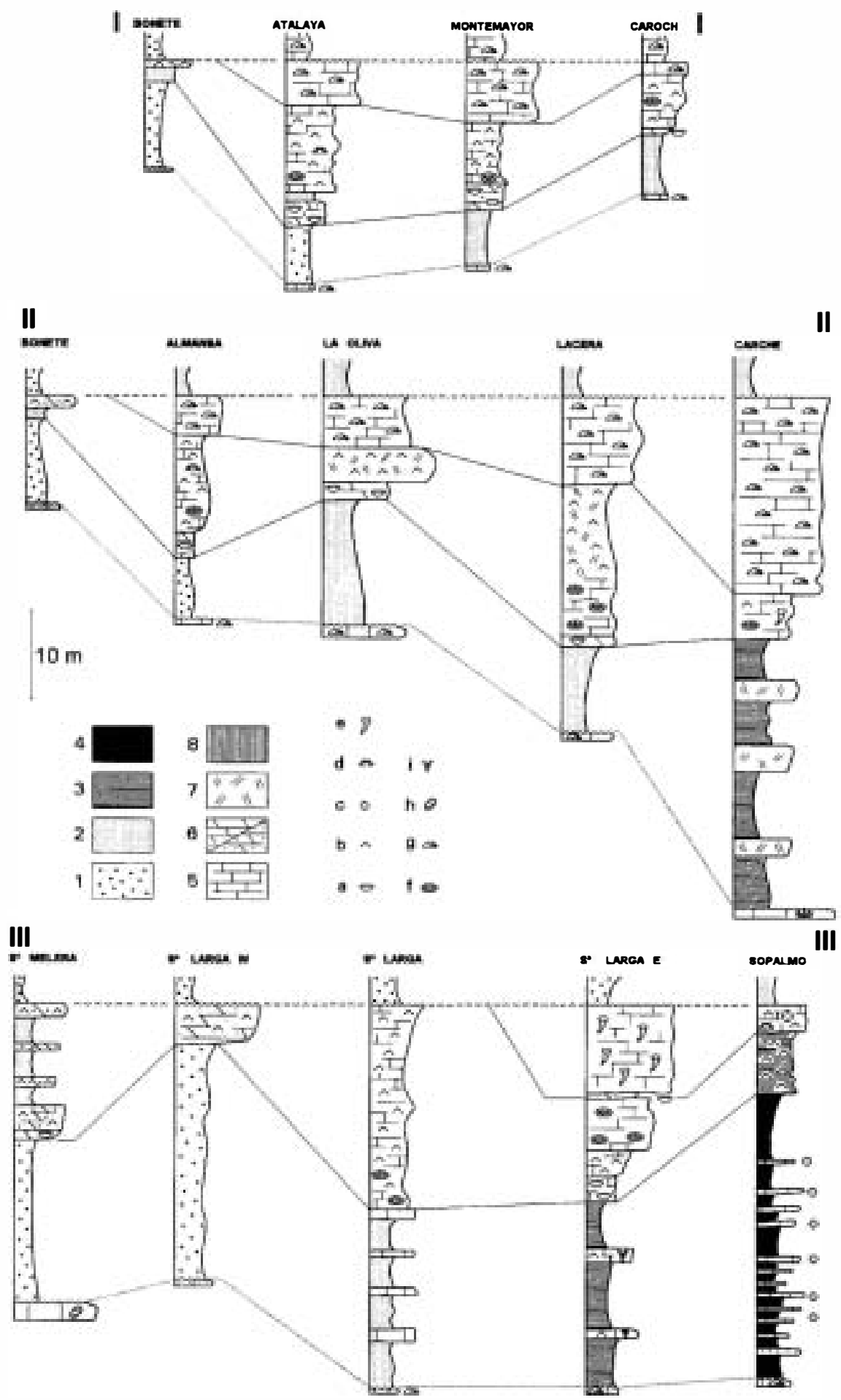


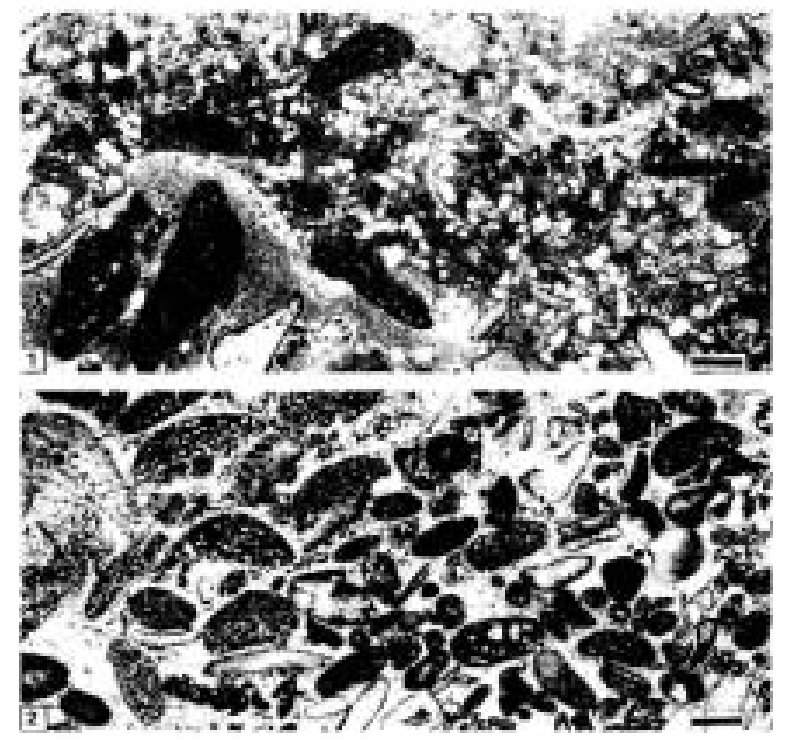

Fig. 3. Palorhitolina facies: coastal zone. $I=$ Sandy (detrital quartz) packstone with peloidal and bioclastic fragments, containing scattered, poorly preserved Palorhitolina transported shells (El Carche). 2 = Bioclastic peloidal grainstone with rounded Palorhitolina shells with a high density of aggregated quartz grains (Sierra Larga). Scale bar is $1 \mathrm{~mm}$.

dominated packstones containing small amounts of clay, are here the cardinal facies (Fig. 4: 1 ). Bioturbation is well developed and macrofauna (brachiopods, echinoids and small sized corals) as well as Palorbitolina are associated with other large foraminifera, e.g. Choffatella gr. decipiens, Gaudryina? ectypa Arnaud-Vanneau and miliolids. Sedimentological and biological parameters suggest a quiet, open, shallow water environment, with limited but significant fine grained siliciclastic input.

(4) Outer platform deposits. Four distinctive facies are ascribed to this depositional setting.

*Bioclastic packstones with abundant colonial corals; Palorbitolina in the matrix is interpreted to be nearly in-situ biological components.

* Palorbitolina packstones with colonial corals and caprinid rudists, generated near coral-dominated communities, in hydrodynamically low to intermediate energy.

* Decimeter cross-bedded Palorbitolina grainstones closely associated with coral beds with in-situ
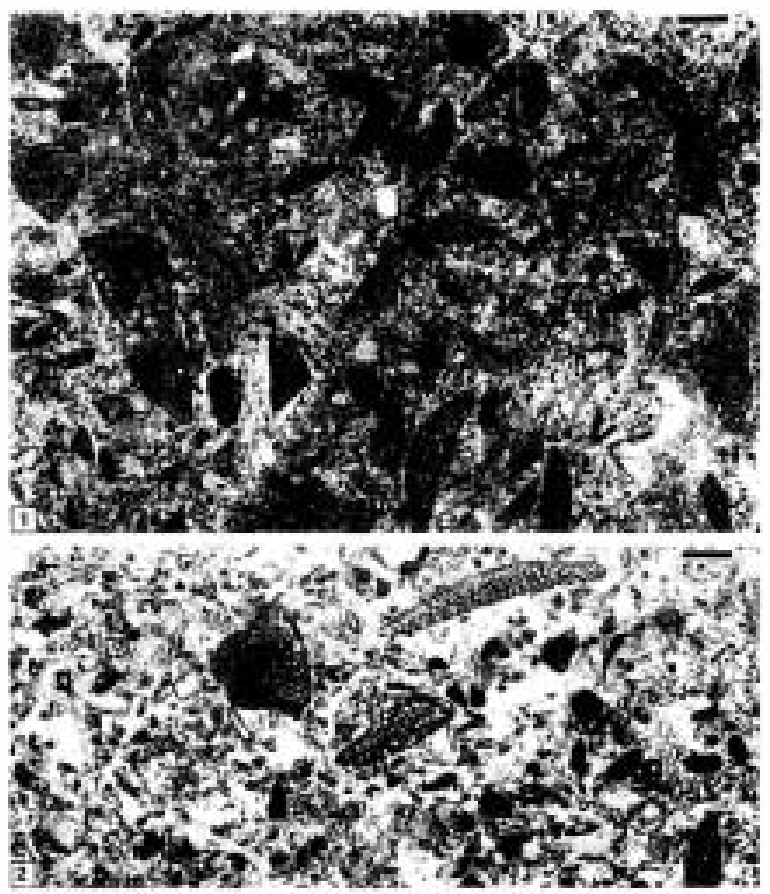

Fig. 4. Palorhitolina facies: platform settings. $I=$ Platform interior: Palorbitolina packstone in a micritic/peloidal matrix with small foraminifera (Caroch). $2=$ Outer platform: peloidal bioclastic packstone-grainstone with hydrodynamically displaced Palorhitolina (Montemayor). Scale bar is $1 \mathrm{~mm}$.

colonies, genetically related to the foregoing facies in an hydrodynamically more active environment. * Large scale cross-bedded Palorbitolina packstones-grainstones (talus deposits) forming hydrodynamically driven, meter-thick accumulations, fed by the drift of Palorbitolina-dominated adjacent communities.

In outer platforms settings Palorbitolina is therefore recorded either as an in-situ or displaced organism. Moreover they are not always strictly dominant and are associated with bioclastic components (coral and bivalve fragments) as well as small and large foraminifera (e.g. miliolids, lituolids) (Fig. 4: 2).

(5) Outer shelf deposits. Palorbitolina wackestones (Fig. 5) occur as intercalations in decameterthick marly units, containing solitary corals (Montlivaltiidae) and relatively deep water bivalves, e.g. Plicatula. Aetostreon, trigoniids, brachiopods and some infaunal echinoids. Associated foramini- 


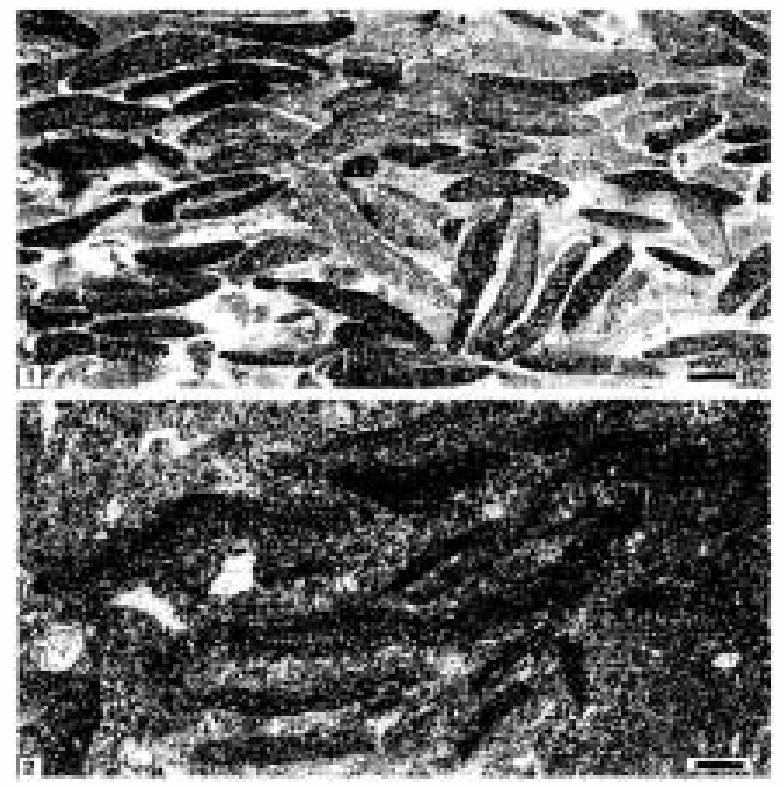

Fig. 5. Palorbitolina facies: platform/outer shelf transition and outer shelf settings. $l=$ Platform/outer shelf transition: Palorbitolina packstone with dominance of large flat forms (Sierra Larga). 2 = Outer shelf: Palorbitolina packstonewackestone; the lutitic matrix contains minute clastic quartz grains also found in the test of Palorbitolina with large, flat morphologies (Sopalmo). Scale bar is $1 \mathrm{~mm}$.

fera correspond to representatives of Lenticulina, Dorothia, Epistomina and Hedbergella; glauconite is common.

From platform interior to outer shelf facies, Palorbitolina can display significant morphological and structural changes. Shallow water forms tend to be smaller and higher than the deeper water ones (Fig. 6), i.e. flatness and diameter seem to be depth related, a pattern well known for some modern forms and interpreted as an adaptive trend
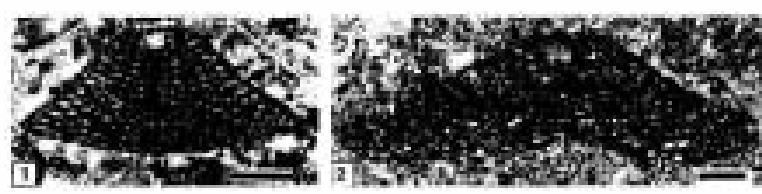

Fig. 6. Morphologic and structural variations in Palorbitolina lenticularis related to distinctive palaeoenvironmental conditions. $l=$ "Conical" form with microgranular structure from shallow water settings (platform interior). $2=$ Large flat form with abundant siliciclastic quartz aggregation, from deeper water settings (outer shelf). Scale bar is $1 \mathrm{~mm}$. to light reduction with depth (Hottinger, 1982, 1983; Hallock, 1979, 1985). Wall structure is microgranular, micritic or densely agglutinated with quartz grains or spherical sponge spicules (ascribed to the family Geodidae) (Hartman, 1981 ). Wall structure is mainly related to the composition of the sedimentary substrate and has therefore no clear bathymetric significance.

\section{Spatial organization}

The palaeogeographic configuration displayed on Fig. 7 corresponds with the base of the sub-sequence to which pertain the Palorbitolinabearing beds.

The analysis of the above mentioned cross sections I-III, shows the following aspects:

(1) Palorbitolina facies widen in a transgressive context; progradational trends are only locally present (Prebetic domain) on top of Palorbitolina units,

(2) Terrigenous clastics are therefore restricted to a narrow littoral belt. Palorbitolina facies developed in the coastal zone with limited clastic inputs.

(3) The correlative transgression is marked by the expansion of marine sediments over antecedent continental ones in the coastal zone, coeval with a deepening phase in the distal domains.

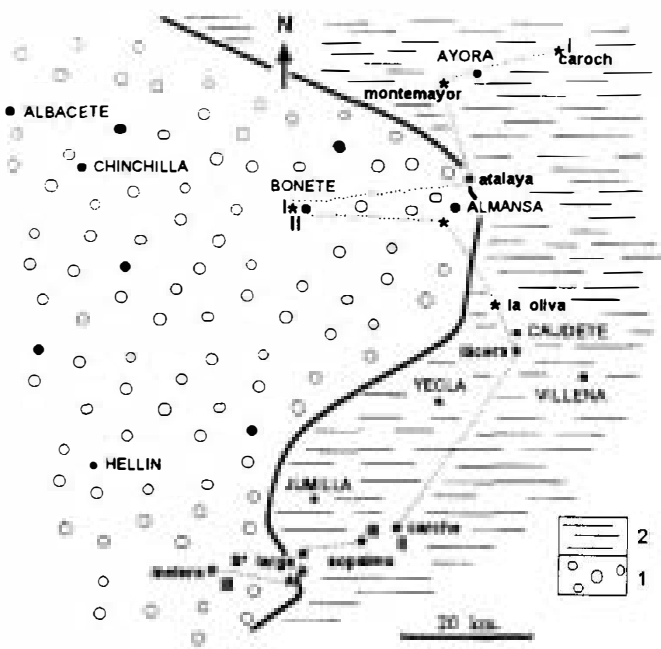

Fig. 7. Palaeogeographical configuration at the beginning of the subsequence to which pertain the Palorbitolina bearing beds. $l=$ Continental terrigenous sediments. $2=$ Marine mixed carbonate siliciclastic sedimentation. 
(4) Progressive deepening from the littoral towards the outer shelf is clearly expressed in the Prebetic domain but less developed in the Albacete/Iberic domain and the Albacete/Prebetic domain.

In the Albacete/Iberic region, illustrated in cross section I (Fig. 8), over some $50 \mathrm{~km}$, off the coastal zone, Palorbitolina facies show limited lateral variations.This pattern is related to the palaeogeographic configuration of the Albacete-Iberic embayment with a nearly flat bottom, and a relatively shallow depth, which lacked any high energy edge zone and/or topographic anomalies.

In the Albacete/Prebetic region, illustrated by cross section II (Fig. 8), across $80 \mathrm{~km}$, the Albacete-Prebetic boundary (Caudete area) is marked by significant facies changes from the Palorbitolina platform interior type to the Palorbitolina-coral outer platform type. This spatial modification is just located on a major palaeostructural anomaly, the activity of which is documented from earliest Cretaceous to late Aptian times (Arias et al., 1987; Vilas et al., 1993). This area corresponds also to a change from an inner ramp to an outer ramp setting. The corresponding hinge zone exerted a relatively high hydrodynamic control generating swell and/or tidal bars. The platform/ramp system was therefore more or less rimmed.

In the Prebetic region a well expressed lateral facies differentiation also occurs (cross section III, Fig. 8) over more than $50 \mathrm{~km}$ if palinspastically
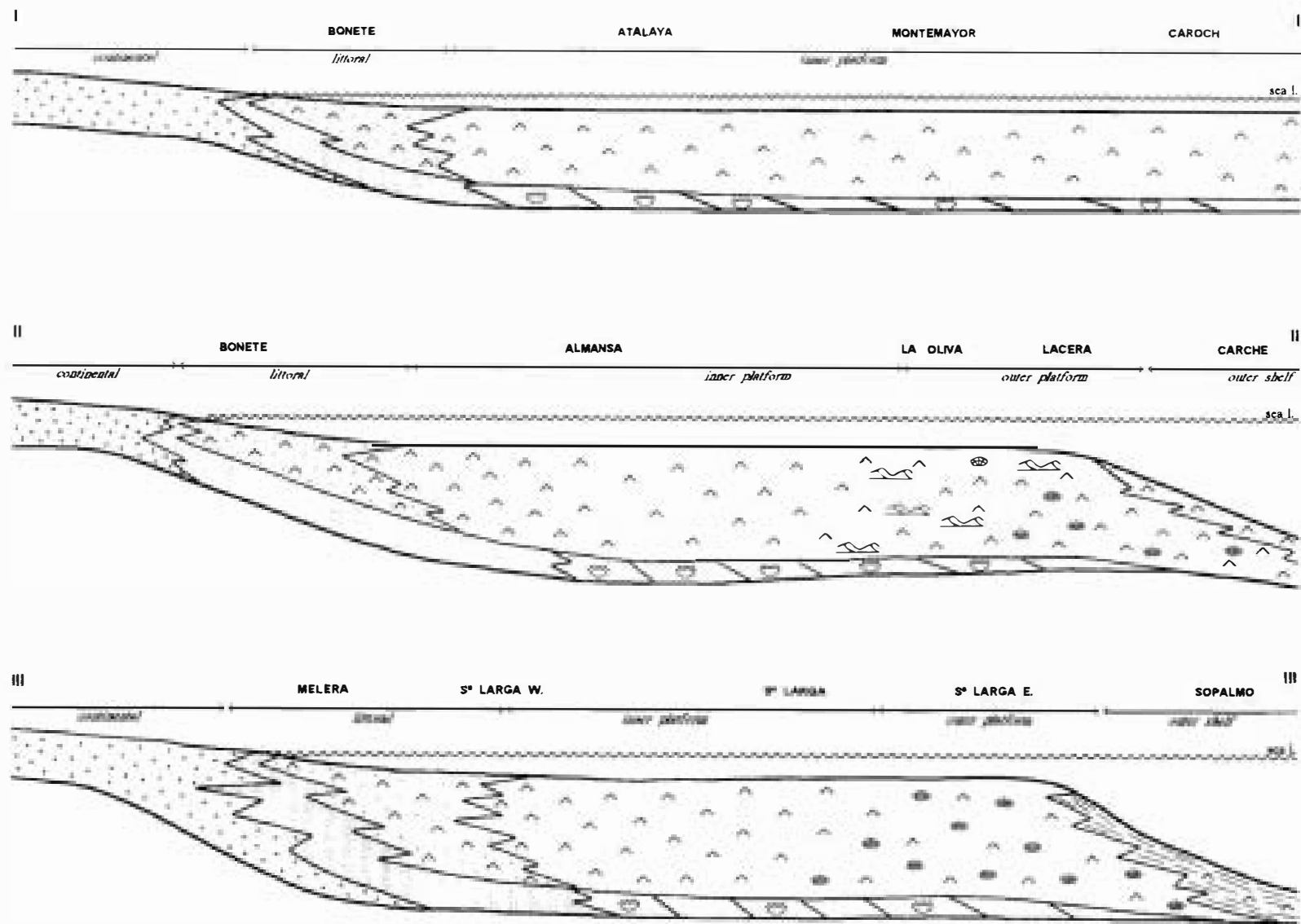

Fig. 8. Spatial organization and facies relationships of the Palorhitolina beds in the different cross sections. Legend see Fig. 2. Not to scale. 
reconstructed. The hydrodynamically generated swell/tidal bars were here replaced by a coral/Palorbitolina facies, passing rapidly to an outer shelf facies.

Whatever the facies lateral differentiation, the sedimentary variability within Palorbitolina beds is far less than that in the rudist platform system occurring before and after the Palorbitolina spreading phase.

\section{Conclusions}

Palorbitolina facies were considered hitherto as a typical component of the Upper BarremianLower Aptian carbonate platform sediment spectrum and consequently ascribed by many authors to a specific environmental setting. As so it was regarded has a zonal index in platform reconstructions (e.g. radial cross sections). The Iberic-Prebetic example documents a model in which the Palorbitolina facies is present throughout the whole platform system from the littoral to the outer shelf area. This Palorbitolina facies obviously involves distinctive subfacies. The spreading of Palorbitolina dominated sediments is related to:

- firstly, an important terrigenous runoff,

- a transgressive context,

-a change in platform morphology : there is a clear tendency to produce ramps, i.e. gently deepening systems, the sedimentary pattern of which is mainly controlled by bathymetry, rather than platforms, i.e. near flat horizontal systems without any significant depth variations, the sedimentary pattern of which, mainly expressed by distality/ proximality trends, is controlled by hydrologic and hydrodynamic parameters.

The increasing terrigenous supply followed by a transgressive phenomenon, suggest a tectonoclimatic control possibly associated with a subsequent "relative sea level rise". As proposed earlier (Arias et al., 1987) tilting of the antecedent platform could have been a causal factor in deepening of the central part of the basin and possible uplifting of the adjacent land, resulting in clastic exportation. Assuming that the near homoclinal morphology was created during the onset of the Palorbitolina facies expansion, the corresponding ramp did not change to a platform prior to the subsequent coral/rudist carbonate sequence. Sediment accumulation rates for the Palorbitolina facies were therefore probably far less from those of the coral/ rudist facies. Terrigenous runoff could have increased nutrient supply favouring fast growing organisms with asexual reproduction (Birkelund, 1988): this provides a possible scenario for large foraminifera such as Palorbitolina, contrasting with the "symbiotic model" assumed by Hottinger (1982) postulating low nutrient levels (see discussion in Hallock, 1985).

Data collected by us in various carbonate platform system from Iberia and other Mediterranean regions, suggest that the model investigated here could also apply for Mesorbitolina and other large Orbitolininae recorded in the Late Aptian-Albian time span.

The SE Spanish model consequently documents the possibility for Orbitolina episodes to represent short but major breaks in the temporal and spatial evolution of Mid Cretaceous carbonate platforms.

\section{Acknowledgements}

The authors thank A. Arnaud-Vanneau and R.W. Scott for constructive and helpfull on this manuscript.

\section{References}

Arnaud, H., 1981. De la plate-forme urgonienne au bassin vocontien: le Barremo-Bedoulien des Alpes occidentales entre Isere et Buech. Geol. Alp., 12, 804 pp.

Arnaud-Vanneau, A., 1968. Etude statistique et morphologique des Orbitolines du synclinal d'Autrans (Vercors septentrional). Geol. Alp., 44: 25-48.

Arnaud-Vanneau, A., 1975. Reflexion sur le mode de vie de certains Orbitolinides (Foraminiféres) barremo-aptiens de l'Urgonien du Vercors. C.R. Seanc. SPHN Geneve, 10(2-3): 126-130.

Arnaud-Vanneau, A., 1980. Micropaléontologie, paléoecologie et sédimentologie d'une plate-forme carbonatée de la marge passive de la Téthys. Geol. Alp., 11, 874 pp.

Arias, C., 1978. Estratigrafía y paleogeografía del Jurásico superior y Cretácico inferior del nordeste de la provincia de Albacete. Thesis. Univ. Madrid, 3, 299 pp.

Arias, C., Masse, J.P. and Vilas, L., 1987. Modalités d'installa- 
tion et de developpement des plates-formes carbonatées urgoniennes à la charnière des domaines iberique et betique (Espagne meridionale) durant l'Aptien inferieur. Transgressions et Regressions du Crétacé. Mem. Geol. Univ. Dijon, 2: 213-223.

Arias, C., Masse, J.P. and Vilas, L., 1991. Anatomía estratigráfica de la plataforma aptiense en la región de Jumilla (prebético de Murcia). In: 3rd Coloq. Cretácico de España Abstr., p. 11.

Birkeland, C., 1988. Second-order ecological effects of nutrient input into coral communities. Galaxea, 7: 91-100.

Champetier, Y. and Moullade, M., 1970. Correlations des facies à Orbitolinidae à l'Est du Rio Albaida, provinces de Valence et d'Alicante (Espagne). Consequences stratigraphiques, paleoecologiques et paleogeographiques. Bull. Soc. Geol. Fr., 7,12,5: 765-773.

Company, M., García-Hernández, M., López-Garrido, A.C., Vera, J.A. and Wilke, H., 1982. Análisis y distribución de facies del Cretácico inferior del Prebético en la provincia de Alicante. Cuad. Geol. Ibér., 8: 563-578.

Cugny, P., 1975. Utilisation de methodes quantitatives en paleoecologie. Application à l'étude des microfacies du Barremien terminal et du Bedoulien de l'Estremadura (Portugal). Thesis. Univ. P. Sabatier, Toulouse, 120 pp.

Douglass, R.C., 1960. The foraminiferal genus Orbitolina in North America. U.S. Geol. Surv. Prof. Pap., 333.

Douvillé, H., 1900. Sur la distribution géographique des Rudistes, des Orbitolines et des Orbitoides. Bull. Soc. Géol. Fr. (3), 28: 222-235.

Fourcade, E., 1970. Le Jurassique et le crétacé aux confins des chaînes bétiques et ibériques (Sud-Est de l'Espagne). Thesis. Univ. Paris VI, 427 pp.

García-Hernández, M., 1978. El Jurásico terminal y el Cretácico inferior en las Sierras de Cazorla y del Segura (zona prebética). Thesis. Univ. Granada, 190, 344 pp.

García-Hernández, M., 1981. Biozonation du Crétacé infèrieur à l'aide des Foraminifères benthiques et des Algues Dasycladacees dans le Prebetique occidental (Cordillères Betiques, Espagne). Géobios, 14(2): 261-267.

García-Quintana, A., 1977. Jurásico terminal y Cretácico inferior en la región central de la provincia de Valencia y noreste de la provincia de Albacete. Thesis. Univ. Madrid, $1,334 \mathrm{pp}$.

Gupta, S.B.K. and Grant, A.C., 1971. Orbitolina, a Cretaceous larger foraminifera, from Flemish Cap: paleoceanographic implications. Science, 173: 934-936.

Gušić, I., 1981. Variation range, evolution and biostratigraphy of Palorbitolina lenticularis (Blumenbach) (Foraminiferida, Lituolacea) in the Lower Cretaceous of the Dinaric Mountains in Yugoslavia. Palaeontol. Z., 55(3-4): 191-208.

Hallock, P., 1979. Trends in test shape with depth in large symbiont-bearing foraminifera. J. Foram. Res., 9: 61-69.

Hallock, P., 1985. Why are larger foraminifera large?. Palaeobiology, 11: 195-208.

Hartman, W.D., 1981. Form and distribution of silica in sponges. In: T.L. Simpson and D.E. Volcani (Editors),
Silicone and Siliceous Structures in Biological Systems. Springer, Berlin, pp. 453-493.

Hofker, J., 1963. Studies on the genus Orbitolina (Foraminiferida). Leidse Geol. Meded., 253 pp.

Hottinger, L., 1982. Larger Foraminifera, Giant cells with a historical background. Naturwissenschaften, 69: 361-371.

Hottinger, L., 1983. Processes determining the distribution of larger foraminifera in space and time. In: J. Meulenkamp (Editor), Reconstruction of Marine Paleoenvironments. Utrecht Micropaleontol. Bull., 30: 239-253.

Loeblich, A.R. and Tappan, H., 1988. Foraminiferal Genera and Their Classification. Van Nostrand Reinhold. New York, 970 pp.

Luperto-Sinni, E., 1979. I microfossili del livello a "Palorbitolina lenticularis" delle Murge baresi. Riv. Ital. Paleontol., 85(2): 1-70.

Luperto-Sinni, E. and Masse, J.P., 1982. Contributo della paleoecologia alla paleogeografía della parte meridionale della piattaforma apula nel Cretaceo inferiore. Geol. Rom., 21: 859-877.

Luperto-Sinni, E. and Masse, J.P., 1992. Biostratigrafía dell' Aptiano in facies di piattaforma carbonatica delle Murge baresi (Puglia, Italia meridionale). Riv. Ital. Paleontol. Stratigr., 98(4): 403-424.

Mas, J.R., 1981. El Cretácico inferior de la región noroccidental de la provincia de Valencia. Thesis. Univ. Complutense. Madrid, 8, 408 pp.

Masse, J.P., 1976. Les calcaires urgoniens de Provence (Valanginien-Aptien inferieur). Stratigraphie, Paleontologie, les paleoenvironments et leur evolution. Thesis. Univ. Marseille, $445 \mathrm{pp}$.

Masse, J.P., 1984. Données nouvelles sur la stratigraphie de l'Aptien carbonaté de Tunisie centrale, consequences paleogeographiques. Bull. Soc. Geol. Fr., 7,36,6: 1077--1086.

Masse, J.P., 1992. The Lower Cretaceous Mesogean benthic ecosystems: palaeoecologic aspects and palaeobiogeographic implications. Palaeogeogr. Palaeoclimatol. Palaeoecol., 91: 331-345.

Meza, J.G., 1980. El género Orbitolina en Mexico y su distribución estratigráfica. Rev. Inst. Mex. Pet., 12: 4-33.

Moullade, M., 1965. Contribution au problème de la classification des Orbitolinidae (Foraminiferida, Lituolacea). C.R. Acad. Sci. Paris, 260: 4031-4178.

Murray, J.W., 1991. Ecology and Palaeoecology of Benthic Foraminifera. Longman, New York, 397 pp.

Pelissie, T., Peybernes, B. and Rey, J., 1982. Tectonique des plaques et paléobiogéographie des Grands Foraminifères benthiques et des algues calcaires du Dogger à l'Albien sur le pourtour de la Mesogée. Bull. Soc. Geol. Fr., 7,24(5-6): 1069-1076.

Pérès, J.M., 1961. Océanographie biologique et écologie marine. Univ. de France, Vendôme, 541 pp.

Perkins, B.F., 1974. Paleoecology of a rudist reef-complex in the Comanche Cretaceous Glen Rose limestone of Central Texas. Geosci. Man, 8(1): 131 $\cdots 173$.

Peybernes, B., 1982. Les Orbitolinidés crétacés d'Afrique. Essai de synthèse. Cah. Micropaleontol., 2: 13-28. 
Peybernes, B. and Forster, R., 1987. Présence d'une association micropaléontologique de la zone à Praeorbitolina cormyi (Aptien inférieur) dans l'Urgonien de Tanzanie méridionale. Implications paléogeographiques au niveau de la marge indienne de l'Afrique. Géol. Mediterr., 14(2): 143-151.

Rey, J., 1975. Observations sur l'ecologie des Orbitolines et des Choffatelles dans le Crétacé inferieur d'Estremadura (Portugal). C.R. Acad. Sci. Paris, 276: 2517-2520.

Schroeder, R., 1963. Palorbitolina, ein neues subgenus der gattung Orbitolina (Foram.). Neues Jahrb. Geol. Pälaontol. Monatsh., 117: 346-359.

Scott, R.W., 1990. Models and stratigraphy of Mid-Cretaceous reef communities, Gulf of Mexico. Soc. Sediment. Petrol., 2, $102 \mathrm{pp}$.
Simmons, M.D. and Hart, M.B., 1987. The biostratigraphy and microfacies of the Early to mid-Cretaceous carbonates of Wadi Mi Aidin, Central Oman Mountains. In: Hart (Editor), Micropaleontology of Carbonate Environments. Ellis Horwood, Chichester, 10, pp. 176-207.

Vilas, L., Masse, J.P. and Arias, C., 1993. Aptian mixed terrigenous and carbonate platforms from Iberic and Prebetic regions, Spain. In: T. Simo et al. (Editors), Cretaceous Carbonate Platforms. Am. Assoc. Pet. Geol. Mem., 56: 243-251.

Wolcke, F. and Scholz, J., 1988. Über die paläobiogeographische Bedeutung eines Vorkommens caprinider Rudisten aus der Unterkreide von Cebu (Philippinen). Mitt. Geol.Paläontol. Inst. Univ. Hamburg, 67: 121-133. 